\title{
The Role of Universities in Regional Development: Case of Russia
}

\author{
Dmitry Rodnyansky \\ Kazan Federal University \\ Kazan, Russia \\ drodnyansky@gmail.com
}

Victor Kolesnikov

Russian Presidential Academy of National Economy and Public Administration, Lipetsk branch

Lipetsk, Russia

glawbuch@lipetsk.ru

Anna Avtsinova

LKITeM (branch) FSBEI HE MSUTM name's K.G.

Razumovsky (FKI)

Lipetsk, Russia

a.avtsinova@mail.ru

\author{
Ivan Makarov \\ Russian Presidential Academy of National Economy and \\ Public Administration, Lipetsk branch \\ Lipetsk, Russia \\ excellennz@gmail.com
}

\author{
Ilya Lvov \\ Kazan Federal University \\ Kazan, Russia \\ ilya.1voff2015@yandex.ru
}

Elena Khryuchkina

K. G. Razumovsky Moscow state University of technologies and management

Lipetsk, Russia

\begin{abstract}
Universities are not only centers of education and science, but also new participants in the country's socio-economic development. With a wide range of opportunities and resources, universities are effectively carrying out their activities, the results of which are reflected in region's indicators. The article describes the assessment of the presence and tightness of the relationship between indicators of higher education institutions of the Russian Federation and regional development parameters, using an author's methodology based on econometric data calculations. During the study, a regression model was built, which was used to obtain forecast values for the future period.

As the result, we made the conclusion about the nature and degree of universities' influence on regional development.
\end{abstract}

Keywords: higher education, universities, regional development, region, territorial development, public administration, competitiveness

\section{INTRODUCTION}

The dynamic development of the modern world to a large extent affects many aspects of human life and a huge number of industries. Thus, the socio-economic development of modernity places human capital at the forefront and predetermines it as the most important resource necessary for the further improvement of society. This implies the following need - increasing the importance and quality of the educational process, including higher education. For the Russian Federation, this task is relevant, since it is the effectiveness of state policy in the field of education that will determine the further development of the state and stimulate the increase of its competitiveness in the international arena.

An analysis of education policy will be carried out by studying the influence of higher education institutions on territorial development using the example of the Russian Federation, where universities of a special type - national research universities - will be taken as objects of study. Their peculiarity is a limited period of validity of their status, namely ten years, during which universities should demonstrate the effectiveness of their activities. The hallmarks of a research university also determine the ability to effectively carry out educational and scientific activities based on the principles of integration of science and education. The most important features of national research universities are the presence of a highly effective system of training masters and highly qualified personnel, the ability to generate knowledge and provide an efficient transfer of technology to the economy, and to conduct a wide range of basic and applied research.

In this regard, the relevance of this work is justified by the need to conduct a scientific analysis of the impact of higher education institutions on the socio-economic development of territories [1, 2, 3, 4], implemented through ongoing government policies aimed at improving the quality of the scientific and educational environment. The lack of sufficient 
I. Lendel in his article empirically proved that the activities empirical data on the parameters that influence regional development is also an incentive for research, since their determination will stimulate the socio-economic development of the country as a whole.

\section{LITERATURE REVIEW AND RESEARCH METHODS}

Studying the socio-economic impact of institutions of higher education such as a university is a problem that has attracted considerable attention from researchers. According to B. Kotosz, the effects of university activities can be observed in many areas of the economy. Defining them is the standard tool used by Western universities to convince state legislatures of the importance of spending on higher education. [5]

In a joint scientific work with B. Kotosz, M-F. GaunardAnderson, M. Lukovics argue that studies of the influence of universities on the regions are carried out using various methods, and their results are difficult to compare. The authors themselves in their scientific work examined the influence of universities in Hungary and France on regional development, located in countries with different levels of economic development, the results of which showed an equal level of influence [6].

R. Garrido-Iserte and M.T. Gallo-Rivera sees the university as a stream of income and expenses that has a positive impact on local economic development. These effects can be divided into two categories: the effects associated with human capital and research, and the effects associated with costs and their multiplier effect on the local economy [7].

The roles of universities as large educational institutions, sources of knowledge and providers of general educational experience, according to A. Popescu, are used to classify the regional impact of universities. They act as local integrators of various flows of national policies in the interests of the region: labor and employment policies, industrial policies, science and technology policies, education and training policies, and territorial development policies [8].

Evaluation of universities as producers of innovative products influencing regional development is also becoming a modern line of research. L. Blume, T. Brenner, G. Buenstorf argue that if universities were previously evaluated by graduates and their contribution to the region's economy, now educational institutions are becoming important players in the innovative development of territories [9].

M. Gjelsvik in his work explores the role of universities in the development of regions, illustrating how universities contribute to the transformation and expansion of the region's economic development through interaction with industrial enterprises. The author believes that universities should play a large role in regional development, taking into account the peculiarities of the development of the region in their strategies [10].

The definition of universities should be closely linked with the development strategies of a region or a specific industry, A. Bonaccorsi considers in his article. In order for universities to influence regional development, they need to focus on the priority industry of a particular region [11]. of research universities have an impact on socio-economic development. It is argued that large universities with a large amount of research and development work [12] are of economic importance.

The authors of S. Bagchi-Sen, H.L. Smith They argue that the impact of universities on the economic development of regions has not yet been fully explored, since evaluating this impact analyzes the largest universities with a large volume of research and development. It is also noted that special attention when working with universities should be given to the commercialization of their activities and the possibility of transferring accumulated experience to industrial enterprises [13].

The need to expand approaches to universities as fullfledged entities that influence regional economic development is described in an article by R. Pugh, E. Hamilton, S. Jack, A. Gibbons. The authors explore the growing attention to universities as key actors in managing regional economic development through activities to support the development of entrepreneurship in their regions [14].

The study of the impact of universities on the socioeconomic development of the regions is an urgent task, which confirms the increased interest in this topic from the scientific community $[15,16,17]$.

After studying the work of researchers in a given topic, the authors proposed their own methodology, which allows, on the basis of regression analysis, to assess the impact of performance indicators on the system under study, as well as to predict their change based on the construction of the paired regression equation. In the framework of this study, the degree of dependence of indicators of socio-economic development of the region on changes in the performance of national research universities in the period from 2014 to 2018 was revealed, and a forecast was made for 2019.

As research methods, both general theoretical methods were used, which include classification, analysis and synthesis comparison and comparison of the generated data. As the calculation method, the econometric method was applied with the construction of paired regression equations to obtain predicted values.

At the initial stage of the study, the following universities were selected:

- Kazan National Research Technological University;

- Belgorod National Research University;

- Tomsk National Research Polytechnic University;

- Irkutsk National Research Technological University;

- Perm State National Research University.

According to the data published in statistical compilations, as well as university reporting documents, a selection of regressors was carried out, which supposedly can influence the socio-economic development of territories. (table I). of the information received, as well as practical, namely, 
of the dependent indicators had the most pronounced polynomial dependence with independent factors.

We forecast changes in the level of wages and gross regional product in the Republic of Tatarstan for 2019 and present the results in table II.

TABLE II. EQUATIONS FOR THE FORECAST OF SOCIO-

ECONOMIC INDICATORS IN THE REPUBLIC OF TATARSTAN

\begin{tabular}{|l|l|l|l|}
\hline$Y_{\mathbf{n}} \mathbf{X}_{\mathbf{n}}$ & \multicolumn{1}{|c|}{ Regression equations } & \multicolumn{1}{|c|}{$\mathbf{R}^{2}$} & \multicolumn{1}{c|}{$\begin{array}{c}\text { The } \\
\text { predicted } \\
\text { value of } Y\end{array}$} \\
\hline \multicolumn{4}{|c|}{ Gross regional product (million rubles) } \\
\hline $\mathrm{Y}_{1} \mathrm{X}_{1}$ & $\begin{array}{l}\mathrm{y}=134.58 \mathrm{x}^{2}-50000000 \mathrm{x}+ \\
500000000000\end{array}$ & 0.8119 & 2104083 \\
\hline $\mathrm{Y}_{1} \mathrm{X}_{3}$ & $\begin{array}{l}\mathrm{y}=0.000000008 \mathrm{x}^{2}-19.134 \mathrm{x} \\
+100000000000\end{array}$ & 0.9946 & 2576891 \\
\hline $\mathrm{Y}_{1} \mathrm{X}_{5}$ & $\begin{array}{l}\mathrm{y}=0.000000001 \mathrm{x}^{2}-5.17 \mathrm{x}+ \\
60000000000\end{array}$ & 0.7661 & 1551161 \\
\hline \multicolumn{4}{|c|}{ Salary level (rub.) } \\
\hline $\mathrm{Y}_{4} \mathrm{X}_{1}$ & $\begin{array}{l}\mathrm{y}=0.0032 \mathrm{x}^{2}-129.1 \mathrm{x}+ \\
1 * 10^{6}\end{array}$ & 0.8119 & 24952 \\
\hline $\mathrm{Y}_{4} \mathrm{X}_{3}$ & $\begin{array}{l}\mathrm{y}=1 * 10^{-13} \mathrm{x}^{2}-0.0003 \mathrm{x}+ \\
188036\end{array}$ & 0.9946 & 36471 \\
\hline $\mathrm{Y}_{4} \mathrm{X}_{4}$ & $\begin{array}{l}\mathrm{y}=110.24 \mathrm{x}^{2}-7583.6 \mathrm{x}+ \\
153787\end{array}$ & 0.7661 & 28172 \\
\hline
\end{tabular}

The strongest connection between the gross regional product is observed with the number of students, the volume of R\&D, and income from the extra-budgetary activities of the university. The level of wages in the Republic of Tatarstan, in turn, is associated with a change in the number of students and graduate students of the university, as well as income from extrabudgetary activities. Given the particularities of the methodology, the one that most closely matches the trend and has the highest coefficient of determination is used as a forecast indicator characterizing socio-economic development.

We turn to the results of the forecast of socio-economic indicators in the Perm region.

TABLE III. EQUATIONS FOR THE FORECAST OF SOCIOECONOMIC INDICATORS IN PERM REGION logarithmic, power and exponential, were considered. Those variables that influence the change in socio-economic development in the region were selected those whose determination coefficient was greater than or equal to $60 \%$ for at least one of the types of regression.

The final stage included the construction of paired regression equations for each university to obtain predictive data. As expected values for the future period, the values prescribed in the university development programs developed to obtain the status of a national research university were used.

The main objective of the study was to determine the reliability or falsity of the hypothesis about the influence of national research universities on the socio-economic development of the regions.

\section{RESULTS}

The presented methodology has been tested at five national research universities. Alternately, we present the results of a regression analysis of university performance indicators and the socio-economic development of the region. Note that each

\begin{tabular}{|l|l|l|l|}
\hline $\mathbf{Y}_{\mathbf{n}} \mathbf{X}_{\mathbf{n}}$ & \multicolumn{1}{|c|}{ Regression equations } & \multicolumn{1}{|c|}{$\mathbf{R}^{2}$} & \multicolumn{1}{c|}{$\begin{array}{c}\text { The } \\
\text { predicted } \\
\text { value of Y }\end{array}$} \\
\hline \multicolumn{4}{|c|}{ Gross regional product (million rubles) } \\
\hline $\mathrm{Y}_{1} \mathrm{X}_{1}$ & $\begin{array}{l}\mathrm{y}=-38381 \mathrm{x}^{2}+1 * 10^{7} \mathrm{x}- \\
3 * 10^{8}\end{array}$ & 0.8853 & 2364103 \\
\hline $\mathrm{Y}_{1} \mathrm{X}_{3}$ & $\begin{array}{l}\mathrm{y}=-902810 \mathrm{x}^{2}+6^{*} 10^{7} \mathrm{x}+ \\
3 * 10^{8}\end{array}$ & 0.9684 & 1214086 \\
\hline \multicolumn{4}{|c|}{ Salary level (rub.) } \\
\hline $\mathrm{Y}_{4} \mathrm{X}_{2}$ & $\begin{array}{l}\mathrm{y}=-0.5663 \mathrm{x}^{2}+163.23 \mathrm{x}+ \\
21833\end{array}$ & 0.8548 & 32464 \\
\hline $\mathrm{Y}_{4} \mathrm{X}_{6}$ & $\begin{array}{l}\mathrm{y}=91.426 \mathrm{x}^{2}-1443.3 \mathrm{x}+ \\
29782\end{array}$ & 0.897 & 37364 \\
\hline
\end{tabular}

According to table III, a strong connection with the change in the level of wages in the region is observed with such indicators as the number of graduate students of the university and the number of small innovative enterprises. In turn, a significant part of the university's performance indicators is 
The highest correlation of the gross regional product of the not related to changes in wages in the region. A strong connection with the change in the level of wages in the region is observed with indicators: the number of graduate students of the university and the number of small innovative enterprises.

We calculate the predicted values of the level of socioeconomic development for the Irkutsk region. The results are presented in table IV.

TABLE IV. EQUATIONS FOR THE FORECAST OF SOCIOECONOMIC INDICATORS IN IRKUTSK REGION

\begin{tabular}{|l|l|l|l|}
\hline \multicolumn{1}{|c|}{$\mathbf{Y}_{\mathbf{n}} \mathbf{X}_{\mathbf{n}}$} & \multicolumn{1}{|c|}{ Regression equations } & \multicolumn{1}{|c|}{$\mathbf{R}^{2}$} & \multicolumn{1}{c|}{$\begin{array}{c}\text { The } \\
\text { predicted } \\
\text { value of } Y\end{array}$} \\
\hline \multicolumn{4}{|c|}{ Gross regional product (million rubles) } \\
\hline $\mathrm{Y}_{1} \mathrm{X}_{2}$ & $\begin{array}{l}\mathrm{y}=2246.4 \mathrm{x}^{2}-3 * 10^{6} \mathrm{x}+ \\
1 * 10^{9}\end{array}$ & 0.9068 & 3005261 \\
\hline $\mathrm{Y}_{1} \mathrm{X}_{3}$ & $\begin{array}{l}\mathrm{y}=6^{*} 10^{-9} \mathrm{x}^{2}-5.3092 \mathrm{x}+ \\
1 * 10^{9}\end{array}$ & 0.9587 & 1389694 \\
\hline $\mathrm{Y}_{1} \mathrm{X}_{7}$ & $\begin{array}{l}\mathrm{y}=-3 * 10^{6} \mathrm{x}^{2}+1 * 10^{8} \mathrm{x}- \\
7 * 10^{8}\end{array}$ & 0.7941 & 1120000 \\
\hline \multicolumn{1}{|c|}{ Salary level (rub.) } \\
\hline $\mathrm{Y}_{4} \mathrm{X}_{2}$ & $\begin{array}{l}\mathrm{y}=-0.0157 \mathrm{x}^{2}-32.37 \mathrm{x}+ \\
50060\end{array}$ & 0.9278 & 42894 \\
\hline $\mathrm{Y}_{4} \mathrm{X}_{3}$ & $\begin{array}{l}\mathrm{y}=0.0000000000003 \mathrm{x}^{2}- \\
0.0003 \mathrm{x}+84301\end{array}$ & 0.9545 & 47303 \\
\hline $\mathrm{Y}_{4} \mathrm{X}_{7}$ & $\begin{array}{l}\mathrm{y}=-64.205 \mathrm{x}^{2}+2824.7 \mathrm{x}+ \\
11984\end{array}$ & 0.8943 & 30463 \\
\hline
\end{tabular}

The greatest impact on the change in the GRP of the Irkutsk region is exerted by the number of graduate students, the volume of research and development work, the number of patents received by the university during the reporting period and the number of small innovative enterprises created on the basis of the university. Among the indicators that have a strong relationship with changes in the level of wages in the Irkutsk region, the number of graduate students of the university, the volume of research and development work, and the number of defended dissertations should be included.

The analysis results for the Tomsk region, presented in table V.

TABLE V. EQUATIONS FOR THE FORECAST OF SOCIOECONOMIC INDICATORS IN TOMSK REGION

\begin{tabular}{|l|l|l|l|}
\hline \multicolumn{1}{|c|}{$\mathbf{Y}_{\mathbf{n}} \mathbf{X}_{\mathbf{n}}$} & \multicolumn{1}{|c|}{ Regression equations } & \multicolumn{1}{|c|}{$\mathbf{R}^{2}$} & \multicolumn{1}{c|}{$\begin{array}{c}\text { The } \\
\text { predicted } \\
\text { value of } Y\end{array}$} \\
\hline \multicolumn{4}{|c|}{ Gross regional product (million rubles) } \\
\hline $\mathrm{Y}_{1} \mathrm{X}_{2}$ & $\begin{array}{l}\mathrm{y}=0.8655 \mathrm{x}^{2}-47285 \mathrm{x}+ \\
1 * 10^{9}\end{array}$ & 0.9813 & 580094 \\
\hline $\mathrm{Y}_{1} \mathrm{X}_{3}$ & $\begin{array}{l}\mathrm{y}=1 * 10^{-10} \mathrm{x}^{2}-0.6382 \mathrm{x}+ \\
1 * 10^{9}\end{array}$ & 0.7913 & 272514 \\
\hline $\mathrm{Y}_{1} \mathrm{X}_{7}$ & $\begin{array}{l}\mathrm{y}=14283 \mathrm{x}^{2}-5 * 10^{6} \mathrm{x}+ \\
8 * 10^{8}\end{array}$ & 0.9697 & 603923 \\
\hline \multicolumn{1}{|c|}{ Salary level (rub.) } & 43441 \\
\hline $\mathrm{Y}_{4} \mathrm{X}_{1}$ & $\begin{array}{l}\mathrm{y}=5 * 10^{-6} \mathrm{x}^{2}-1.2096 \mathrm{x}+ \\
52545\end{array}$ & 0.9856 & 39669 \\
\hline $\mathrm{Y}_{4} \mathrm{X}_{2}$ & $\begin{array}{l}\mathrm{y}=1.5032 \mathrm{x}^{2}-2630.5 \mathrm{x}+ \\
1 * 10^{6}\end{array}$ & 0.7041 \\
\hline $\mathrm{Y}_{4} \mathrm{X}_{7}$ & $\begin{array}{l}\mathrm{y}=0.4113 \mathrm{x}^{2}-168.32 \mathrm{x}+ \\
48003\end{array}$ & 0.872 & 34529 \\
\hline
\end{tabular}

Tomsk region of indicators is observed with the number of students, university income from extra-budgetary activities and the number of defended dissertations. Salary, in turn, is related to the number of university students, the number of graduate students and the number of defended dissertations.

Let's move on to forecasting indicators of socio-economic development in the Belgorod region.

TABLE VI. EQUATIONS FOR THE FORECAST OF SOCIOECONOMIC INDICATORS IN BELGOROD REGION

\begin{tabular}{|l|l|l|l|}
\hline \multicolumn{1}{|c|}{$\mathbf{Y}_{\mathbf{n}} \mathbf{X}_{\mathbf{n}}$} & \multicolumn{1}{|c|}{ Regression equations } & \multicolumn{1}{c|}{$\mathbf{R}^{2}$} & \multicolumn{1}{c|}{$\begin{array}{c}\text { The } \\
\text { predicted } \\
\text { value of } Y\end{array}$} \\
\hline \multicolumn{4}{|c|}{ Gross regional product (million rubles) } \\
\hline $\mathrm{Y}_{1} \mathrm{X}_{1}$ & $\begin{array}{l}\mathrm{y}=5.7592 \mathrm{x}^{2}-255023 \mathrm{x}+ \\
3 * 10^{9}\end{array}$ & 0.6889 & 371274 \\
\hline $\mathrm{Y}_{1} \mathrm{X}_{6}$ & $\begin{array}{l}\mathrm{y}=-285212 \mathrm{x}^{2}+3^{*} 10^{7} \mathrm{x}- \\
3 * 10^{7}\end{array}$ & 0.9629 & 818164 \\
\hline $\mathrm{Y}_{1} \mathrm{X}_{7}$ & $\begin{array}{l}\mathrm{y}=-21475 \mathrm{x}^{2}+5^{*} 10^{6} \mathrm{x}+ \\
5 * 10^{8}\end{array}$ & 0.8203 & 790105 \\
\hline \multicolumn{1}{|c|}{ Salary level (rub.) } \\
\hline $\mathrm{Y}_{1} \mathrm{X}_{1}$ & $\begin{array}{l}\mathrm{Y}_{4} \mathrm{X}_{1}: \mathrm{y}=0.0002 \mathrm{x}^{2}- \\
10.079 \mathrm{x}+131691\end{array}$ & 0.7413 & 20435 \\
\hline $\mathrm{Y}_{1} \mathrm{X}_{6}$ & $\begin{array}{l}\mathrm{y}=-5.332 \mathrm{x}^{2}+687.11 \mathrm{x}+ \\
7996.8\end{array}$ & 0.9555 & 33171 \\
\hline $\mathrm{Y}_{1} \mathrm{X}_{7}$ & $\begin{array}{l}\mathrm{y}=-0.5524 \mathrm{x}^{2}+136.66 \mathrm{x}+ \\
20209\end{array}$ & 0.8804 & 29393 \\
\hline
\end{tabular}

From table VI it follows that the strongest connection between the university's activity and the socio-economic development of the Belgorod region is observed by regression models, based on indicators of the number of university students, the number of small innovative enterprises created on the basis of the university and the number of defended dissertations. The greatest connection with the change in the average level of wages is observed with the number of university students, the number of small innovative enterprises created on the basis of the university and the number of defended dissertations.

Based on the regression analysis, we were able to predict changes in the gross regional product and wages of the five regions of the Russian Federation, the data on which are presented in Table VII, based on the performance indicators of national research universities. 
the seven indicators, four had a determination coefficient above $60 \%$. In the Republic of Tatarstan and the Belgorod Region, the number of influencing factors is three. The smallest number of university indicators affecting the region is noted in the Perm Territory.

The research also showed that there is a close relationship between the performance indicators of universities and the parameters of socio-economic development of the regions. Identification of key factors and stimulation of their growth will not only increase the competitiveness of the university, but will also affect various spheres of the population's life.

Foreign authors do not use econometric methods to conduct research based on the identification of such dependencies. This method is complicated by the features of the selection of indicators characterizing the regional development and activities of the university, the values of which would have a close relationship. We have selected the most typical factors by which we can describe the scientific and research potential of universities. By analyzing the totality of dependencies, we were able to identify indicators that are significant in the framework of our study, which can be applied to all universities.

The proposed method is universal in nature, and its application and accounting of the data obtained during it can have a positive effect on the level of socio-economic development of the regions and, as a result, will affect the state economy, which, in our opinion, is of value to the international community.

\section{REFERENCES}

[1] E. Uyarra, "Conceptualizing the regional roles of universities, implications and contradictions", European Planning Studies, 18 (8), 2010, pp. 1227-1246.

[2] H. M. S. Priyanath, K.V.D. Edirisooriya, and M. Shantha, "The impact of decentralized higher education institutions on rural socio economic development: A case study of the Sabaragamuwa University", Symposium Proceeding of the 2nd International Symposium. 2008, pp.113-136.

The econometric calculation of pairwise regression for linear and nonlinear models is a mechanism that allows public authorities to predict and regulate the level of socio-economic development of the region $[19,20]$. Determining the activities of educational institutions that have the greatest impact on the economy is an important task, since it allows the efficient use of the resources held by authorities to achieve the development goals of the region. A feature of econometric research is that it is difficult to determine indicators that really have a close relationship with each other.

Thus, the presented methodology can be used by public authorities in determining indicators that affect socioeconomic development. Based on what results the region plans to achieve, it is necessary to determine the priority areas of university activity.

\section{CONCLUSION}

The research showed that the largest number of factors of socio-economic development among those selected by the authors were identified in the Irkutsk and Tomsk Regions: of
[3] J. Kohoutek, R. Pinheiro, and I. Čábelková, "The Role of Higher Education in the Socio-Economic Development of Peripheral Regions", Higher Education Policy, 30, 2017, pp.401-403.

[4] S. Saude, C. Borralho, I. Féria, and S. Lopes, "The impact of a Higher Education Institution on Socioeconomic Development", the Study Case of the Polytechnic Institute of Beja, Portugal, Copernican Journal of Finance and Accounting, 3, 2014, pp.151-166.

[5] B. Kotosz, "Local Economic Impact of Universities", Analecta Technica Szegedinensia, 1-2, 2013, pp. 22-26.

[6] B. Kotosz, M-F. Gaunard-Anderson, and M. Lukovics, "The Local Economic Impact of Universities: An International Comparative Analysis", The Fourth International Conference in Researching Economic Development and Entrepreneurship in Transitional Economies, Graz (Austria), 2015, pp. 22-24.

[7] R. Garrido-Iserte and M. T. Gallo-Rivera, "The impact of the university upon local economy: three methods to estimate demand-side effects", The Annals of Regional Science, $44(1), \quad 2010$, pp. 39-67.

[8] A. Popescu, "The University as a Regional Development Catalyst: Frameworks to Assess the Contribution of Higher Education to Regional Development", European Economic Recovery and Regional Structural Transformations, 2011, 10 p. 
[15] A. Valero and J. Van Reenen, "The economic impact of universities: Evidence from across the globe", Economics of Education Review, Elsevier, 2019, 68, pp. 53-67.

[9] L. Blume, T. Brenner, and G. Buenstorf, "Universities and sustainable regional development: introduction to the special issue", Review of Regional Research, 37 (2), 2017, pp. 103-109.

[10] M. Gjelsvik, "Universities, innovation and competitiveness in regional economies", International Journal of Technology Management, 76 (1-2), 2018, pp. 10-31.

[11] A. Bonaccorsi, "Addressing the disenchantment: universities and regional development in peripheral regions", Journal of Economic Policy Reform, 20(4), 2016, pp.293-320.

[12] I. Lendel, "The Impact of Research Universities on Regional Economies: The Concept of University Products", Economic Development Quarterly, 24 (3), 2010, pp. 210-230.

[13] S. Bagchi-Sen and H. L. Smith, "The Role of the University as an Agent of Regional Economic Development", Geography Compass, 6 (7), 2012, pp. 439-453.

[14] R. Pugh, E. Hamilton, S. Jack, and A. Gibbons, "A step into the unknown: universities and the governance of regional economic development", European Planning Studies, 24 (7), 2016, pp. 1357-1373.

[16] A. Sterlacchini, "R\&D, higher education and regional growth: Uneven linkages among European regions", Research Policy, 2008, 37 (6-7), pp.1096-1107.

[17] E. A. Hanushek, "Will more higher education improve economic growth?", Oxford Review of Economic Policy, 2016, 32 (4), pp.538-552.

[18] C. Schlump and T. Brenner, "University education, public research and employment growth in regions an empirical study of Germany", Opening Up Innovation: Strategy, Organization and Technology, 2010, $29 \mathrm{p}$.

[19] K. Hermannsson, K. Lisenkova, P. Lecca, P.G. McGregor and J.K. Swales, "The external benefits of higher education", Regional Studies, 51 (7), 2017, pp. 1077-1088.

[20] R. Huggins, R. and F. Kitagawa, "Regional policy and university knowledge transfer: Perspectives from devolved regions in the UK", Regional Studies, 46 (6), 2012, pp. 817-832. 